Golden Age: Jurnal Pendidikan Anak Usia Dini, Volume 3 Nomor 2 (Desember 2019)

ISSN 2549-8371 | E-ISSN 2580-5843

Mhd. Habibu Rahman, Maemonah/ Development of Module Early Childhood Education Based on Panca Amal AlWashliyah to Improve Teacher's Pedagogic Competence in Ra Al-Washliyah Kisaran Kabupaten Asahan Sumatera Utara

\title{
Development of Module Early Childhood Education Based on Panca Amal Al-Washliyah to Improve Teacher's Pedagogic Competence in RA Al-Washliyah Kisaran Kabupaten Asahan Sumatera Utara
}

\author{
Mhd. Habibu Rahman ${ }^{1}$, Maemonah² \\ 1, 2 Magister Pendidikan Islam Anak Usia Dini, UIN Sunan Kalijaga \\ Email: 1habiburahman393@gmail.com,2maemonah@uin-suka.ac.id \\ Article Received: 27 April 2020 \\ Published Article: 03 May 2020 \\ DOI: https://doi.org/10.29313/ga:jpaud.v3i2.5985
}

\begin{abstract}
The purpose of this study was to develop a PAUD module based on the Panca Amal Al-Washliyah and to find out its effectiveness in improving teacher pedagogical competence at RA Al-Washliyah Kisaran. This type of research is research and development ( $R \& D)$. The development process includes planning, design, and development. Product validation was carried out by media experts, material experts, Al-Washliyah administrators, and colleagues. The study results indicate that the product developed is feasible to be used as an independent learning media that can be used by educators. This is based on the validator's overall assessment score, namely media experts, material experts, Al-Washliyah administrators, and colleagues who have been converted in interval data to produce positive gradients. Furthermore, based on the pretest results with scores of 12.25 and a post-test of 25.50, there was an increase in knowledge of pedagogic competencies of 13.25 with a standard gain of 0.76, which was in the "high" category. Observations on teachers' pedagogical competence activities showed that 93\% were in the "very high" category. Based on these results, the modules developed were effective in improving teacher pedagogical competencies.
\end{abstract}

Keywords: Modules; PAUD Based on Five Charities Al-Washliyah; Pedagogic Competence.

\begin{abstract}
Abstrak
Tujuan dari penelitian ini adalah untuk mengembangkan modul PAUD Berbasis Panca Amal AlWashliyah, serta mengetahui efektivitasnya dalam meningkatkan kompetensi pedagogik guru di RA Al-Washliyah Kisaran. Jenis penelitian ini adalah research and depelovment (R\&D). Proses pengembangan meliputi perencanaan, desain dan pengembangan. Validasi produk dilakukan oleh ahli media, ahli materi, pengurus Al-Washliyah, dan teman sejawat. Hasil penelitian menunjukkan bahwa produk yang dikembangkan layak untuk digunakan sebagai media pembelajaran mandiri yang dapat digunakan oleh pendidik. Hal ini didasarkan pada skor penilaian keseluruhan validator yaitu ahli media, ahli materi, pengurus Al-Washliyah, dan teman sejawat yang telah dikonversi dalam data interval menghasilkan gradiasi positif. Selanjutnya berdasarkan hasil pretest dengan nilai 12,25 dan posttest sejumlah 25,50 menunjukkan adanya peningkatan pengetahuan kompetensi pedagogik sejumlah 13,25 dengan gain standar 0,76 yang berada pada kategori "tinggi". Observasi terhadap aktivitas kompetensi pedagogik guru menunjukkan dalam persentase 93\% yang berada pada kategori "sangat tinggi". Berdasarkan hasil tersebut menunjukkan modul yang dikembangkan efektif dalam meningkatkan kompetensi pedagogik guru.
\end{abstract}

Kata Kunci: Modul; PAUD Berbasis Panca Amal Al-Washliyah; Kompetensi Pedagogik. 
Golden Age: Jurnal Pendidikan Anak Usia Dini, Volume 3 Nomor 2 (Desember 2019) ISSN 2549-8371 | E-ISSN 2580-5843

Mhd. Habibu Rahman, Maemonah/ Development of Module Early Childhood Education Based on Panca Amal Al-Washliyah to Improve Teacher's Pedagogic Competence in Ra Al-Washliyah Kisaran Kabupaten Asahan Sumatera Utara

\section{INTRODUCTION}

Education is a shared responsibility between parents, teachers, the community, and the government. The four are related to each other. After children enter the world of formal education, the teacher plays a vital role in education. Teachers, as professionals in education, have a great responsibility for children's learning process to achieve the expected educational goals.

One of the factors that determine the success of the teaching and learning process is the teacher. Therefore being a teacher must have the competence to develop creative and innovative ideas in learning. Early childhood education teachers (PAUD) are required to have useful teaching competencies. Minister of Education and Culture Regulation number 137 of 2014 stated that the competencies that must be possessed by PAUD teachers include pedagogic, personality, professional, and social competencies. (Pendidikan, Kebudayaan, \& Indonesia, 2014)

Pedagogic competence is one of the competencies that must be possessed by every teacher, including PAUD teachers. Pedagogic competencies include understanding children as students, the ability to design learning, carry out learning, carry out an evaluation of learning, and the ability to develop the full potential of students.

It is natural for PAUD teachers to master pedagogical competencies so that the learning process in the classroom or outside the classroom can run well. Likewise, for PAUD teachers who teach in Islamic organizations such as Al-Washliyah. AlWashliyah Islamic Community Organization is a Muslim community organization in Indonesia established in Medan on 9th Rajab $1349 \mathrm{H}$, coinciding on November 30, 1930. (AD/ART Al Washliyah, 2010) Ahlus Sunnah wal jam'ah by prioritizing the Shafi'i School. "Al-Washliyah was founded to practice Islamic teachings for the world and hereafter happiness, realize a faithful, pious, safe, peaceful, just, prosperous society blessed by God in the Unitary State of the Republic of Indonesia based on Pancasila, and fostering a strong passion and drive in Indonesian people to participate actively in national development.

The Al-Washliyah organization has educational institutions from the level of Raudhatul Athfal to college. (Riza, 2013) Every teacher in the Al-Washliyah organization is recommended to introduce and teach the material to Al-Washliyahan to every student. Based on the guidelines for implementing early childhood education in AlWashliyah educational institutions, every educator is obliged to create an educational atmosphere that is meaningful, fun, creative, dynamic, and dialogic (PB Al-Washliyah, 2012).

The development of early childhood education learning guidelines in Al-Washliyah is an essential thing to be studied because it will have implications for every educator's teaching competence. Researchers are trying to develop an early childhood learning module based on five AlWashliyah activities known as Panca Amal AlWashliyah. The material presented is a combination of PAUD's basic concepts and the five Al-Washliyah work programs' concepts.

According to Hasbullah Hadi (Syahrul, 2012), the five charities are also called "The Four Pillars of One Buffer." The four pillars in question are education, da'wah, social, and Amar ma'ruf nahi Munkar, while the one buffer in question is hospitality. The four pillars will not be carried out properly without the refutation of hospitality. Related to early childhood education, it requires planting friendship from an early age to support the implementation of education, preaching, social, and Amar ma'ruf nahi mungkar.

Ideally, by understanding Al-Washliyah's five charities in the context of early childhood education, teachers can apply active and fun learning, teach polite communication, understand children's social development, familiarize friendship, and arrange class well. However, there are still many teachers PAUD who do not understand implementing the five Al-Washliyah charities in early childhood education. Based on these problems, the authors assume that RA Al-Washliyah Kisaran requires a learning module that can be used as a guide and reference reading material by teachers so that it is expected to improve teacher pedagogical competence.

Competence is a description of what someone can do at work and what forms of work can be seen. To be able to do a job, a person must have the ability in the form of knowledge, attitudes, and skills relevant to his expertise". (Suyanto \& Asep Jihad, 2013). Broke and Stone (E. Mulyasa, 2009) define teacher competence as "... descriptive of the qualitative nature of teacher behavior appears to be entirely meaningful ..." or a qualitative picture of the nature of meaningful teacher behavior. Broke and Stone's definition of competence then implies a teacher must have pedagogical abilities, including the actualization of the teaching foundation, understanding of students, mastery of teaching knowledge, mastering motivational theories, 
Golden Age: Jurnal Pendidikan Anak Usia Dini, Volume 3 Nomor 2 (Desember 2019) ISSN 2549-8371 | E-ISSN 2580-5843

Mhd. Habibu Rahman, Maemonah/ Development of Module Early Childhood Education Based on Panca Amal Al-

Washliyah to Improve Teacher's Pedagogic Competence in Ra Al-Washliyah Kisaran Kabupaten Asahan Sumatera Utara

compiling curriculum, and preparing learning plans, and evaluating learning.

Pedagogical competence is also closely related to the didactic and methodical abilities that must be possessed by teachers, which include mastering students' characteristics from physical, moral, cultural, emotional, and intellectual aspects, mastering learning theories and learning principles that educate, developing curriculum that related to subjects or areas of development that are being taught, organizing learning that educates, utilizing information and communication technology for the benefit of learning, facilitating the development of potential learners to actualize their various potentials, communicating effectively, empathically, and politely with students, conducting assessments and evaluation for the process and learning outcomes, utilizing the results of assessments and evaluations for the benefit of learning, taking reflective actions to improve the quality of learning." (Marselus R. Payong, 2011).

Pedagogic competence can be interpreted as teachers' ability regarding theoretical mastery and the application process in learning. Based on other opinions said that "Pedagogical competence is the ability of teachers to manage to learn, this competency can be seen from the ability to plan to teach and learning programs, execute the interaction or manage the learning process, and the ability to make learning assessment." (Akhyak et al., 2013)Pedagogical competence is the ability of teachers to manage to learn. This competency can be seen from the ability to plan teaching and learning programs, carry out interactions or manage to learn, and make assessments.

Based on the Minister of Education and Culture Regulation No. 137 of 2014 said that PAUD teacher pedagogical competencies include, "organizing aspects of development in accordance with the characteristics of early childhood, analyzing play theory according to aspects and stages of development, needs, potential, talents, and interests of early childhood, designing early childhood activities based on the curriculum, organizing development activities that educate, utilizing technology, information and communication for the benefit of organizing development activities that educate, developing the potential of early childhood for self-actualization, communicating effectively, empathically, and politely, organizing and making assessment report, evaluation of the process and results of early childhood learning, determine the scope of the target assessment of the process and results of early childhood learning, use the results of the assessment, development and evaluation of programs for the benefit of early childhood development, take reflex action active, corrective and innovative in improving the quality of the processes and results of early childhood development (Pendidikan et al., 2014).

Related to the efforts that researchers do in developing a module means teaching subjects through writing. Therefore, the principles used in developing the module are half formal and half oral, not formal like textbooks. Modules can be developed in various ways, including adaptation, compilation, and self-writing (Purwanto \& Suharto Lasmono, 2007).

"Writing modules is the process of preparing learning material that is systematically packaged so that every user can use it. The preparation of learning modules refers to the competencies contained in the objectives set. The steps of preparing modules based on the reference" (Depdiknas, 2008), among others, analysis of module requirements, is meant to be an activity of analyzing competencies/objectives to determine the number and title of modules needed to achieve competency. The module title's determination is based on the competencies contained in the outline of the specified program. Module needs analysis aims to identify and determine the number and title of modules that must be developed. Drafting intended is a process of preparing and organizing learning material from a competency or sub competency into a systematic unit. The preparation of the draft module aims to provide a draft of a module by established competencies, validation. What is meant is requesting approval or ratification of the module's suitability to the needs. To get recognition of the suitability, validation needs to be done by involving skilled practitioners from the relevant fields in the module. Module validation aims to obtain validation of module compatibility with needs. The module is appropriate for use in learning, testing module drafts, referred to as the use of modules for small-scale participants, to determine the implementation and benefits of modules in learning before the module is used in general. From the trial results, input will be obtained as material for refining the module modules tested. There are two types of trials, namely small-scale trials and largescale trials, revisions, refining modules, after obtaining input from trials and validation activities. The revised draft module aims to make final finalization or comprehensive refinement of the module so that the module is ready to be produced 
Golden Age: Jurnal Pendidikan Anak Usia Dini, Volume 3 Nomor 2 (Desember 2019) ISSN 2549-8371 | E-ISSN 2580-5843

Mhd. Habibu Rahman, Maemonah/ Development of Module Early Childhood Education Based on Panca Amal AlWashliyah to Improve Teacher's Pedagogic Competence in Ra Al-Washliyah Kisaran Kabupaten Asahan Sumatera Utara

according to the input obtained from the previous activity.

\section{RESEARCH METHOD}

This study uses a Research and Development ( $R$ \& D) approach. $R$ \& D research because this research produces a product and is tested from the aspect of the product (Sugiyono, 2016). To produce specific products and test the effectiveness of the product used research that needs analysis. The resulting product is an AlWashliyah-based PAUD module. According to Borg and Gall, this study refers to the definition of research and development, which states that "research and development is a powerful strategy for improving practice. It is a process used to develop and validate educational products (Borg \& M.D. Gall, 1983). Research and development are appropriate strategies to improve the quality of practice. This is the process used to develop and validate educational products. Based on Borg and Gall's opinion, $R \& D$ research is carried out through several stages, namely: (1) potential problems, (2) data collection, (3) product design, (4) design validation, (5) design revision, (6) product trials, (7) product revisions, (8) trial use, (9) product revisions, (10) mass production. Researchers formulate a research phase that suits their needs, time constraints and funds. The stage taken by researchers only reached the 7th stage.

\section{RESULT AND DISCUSSION}

\section{A. Need Analysis of PAUD Module Based on Panca Amal Al-Washliyah}

Based on the observations made in the prestudy, it was found that in the learning process carried out by RA Al-Washliyah Kisaran there are no specific guidelines that reference every teacher in combining Al-Washliyah's work program with the theme of early childhood learning. With every educator's necessity to introduce Al-Washliyah to their students at the early childhood level, it is necessary to have a guide that integrates AlWashliyah's work program contained in AlWashliyah's five charities with early childhood learning material.

Based on interviews conducted in preresearch, with the Head of RA Al-Washliyah Kisaran obtained a description that there are no guidelines used by RA Al-Washliyah in learning, even though the values of the five Al-Washliyah charities have been included in the learning, but the guidelines This RA does not have specific guidelines yet. Therefore based on observations and interviews, the researcher offers a module as a learning guide and a reference for each educator.

\section{B. PAUD Module AI-Washliyah-based PAUD Module Prototype}

The next step after extracting information needs in the field, researchers began to compile a prototype of the PAUD-based Al-Washliyah-based PAUD Module. The design of the material in this module is adjusted to the field's needs identified either based on observations or interviews. This module prototype was made in B5 size paper consisting of:

1. Cover;

2. Table of Contents;

3. Preface;

4. Module Usage Instructions;

5. Introduction;

6. Material (consisting of material objectives, material description, column Come on Record, Come on Story, Did You Know, Come, Judge); and

7. Bibliography and Author Biography.

In determining the material discussed in this module, researchers refer to the Al-Washliyah Work Program called Panca Amal Al-Washliyah, which contains: 1) Education, 2) Da'wah, 3) Social, 4) Amar Ma'ruf Nahi Munkar, 5) Gathering. Then the researchers poured in 5 material discussions, namely:

1. Active and Fun Learning;

2. Positive Communication;

3. Early Childhood Social Skills;

4. Early Childhood Moral Intelligence; and

5. Culture of $3 \mathrm{~S}$ (Smile, Greet, Gathering).

The five materials can add insight and reading material for each educator related to AlWashliyahan material and improve educators' pedagogical competence. In presenting the prototype of this module can be explained as follows:

1. Modules are prepared using Times New Roman font size 12;

2. The presentation of the material is translated into paragraphs;

3. Each material is followed by a column Did you know, Let's Play, Let us tell stories and Let's Record; and

4. There are several picture illustrations for columns or rubrics, and illustrations for story stories and game picture illustrations. 
Golden Age: Jurnal Pendidikan Anak Usia Dini, Volume 3 Nomor 2 (Desember 2019) ISSN 2549-8371 | E-ISSN 2580-5843

Mhd. Habibu Rahman, Maemonah/ Development of Module Early Childhood Education Based on Panca Amal Al-

Washliyah to Improve Teacher's Pedagogic Competence in Ra Al-Washliyah Kisaran Kabupaten Asahan Sumatera Utara

\section{Expert Validation Data}

1. Data Expert Media and Expert Material The media expert who validated this module's feasibility was Dr. Sigit Purnama, M.Pd as a lecturer in the Faculty of Tarbiyah and Teacher Training of UIN Sunan Kalijaga Yogyakarta. The publication of the Al-Athfal journal in 2016 with the title Media Variance in Teaching Calistung at Raudhatul Athfal Babul Jannah Sambas. Moreover, as a material expert who validated the feasibility of this module, Drs. Imran, M.A, serves as the AlWashliyah Education Council of Asahan Regency, which regulates learning activities in Al-Washliyah educational institutions from the Raudhatul Athfal level to High School.

\section{Al-Washliyah Management Data}

Data obtained by giving a questionnaire that includes aspects of appearance, presentation, and material. The Al-Washliyah Regional Administrator, who validated the module quality, was $\mathrm{H}$. Adlan Lubis, S.Pd., M.Pd. (Validator I), and Dr. Hayatsyah (Validator II). The Al-Washliyah Board conducts an assessment by giving a score on each questionnaire statement. Also, the assessment is carried out by providing suggestions for improvement. These two validators are taken with different considerations. One validator is the General Chairperson of the AlWashliyah Regional Leadership, who is active in education. At the same time, the other is the Deputy Secretary of the North Sumatra Regional Leadership. He is also the Head of the Religion Ministry of Asahan Regency. The following are the results of the validation of Al-Washliyah management.

\section{Peer Data}

Data obtained by giving a questionnaire that includes aspects of appearance, presentation, and material. Peers who validate the module quality are Eca Gesang Mentari (Validator I) and Nia Kurniasari (Validator II) as fellow students of the Master Program in the Faculty of Tarbiyah and Teacher Training Studies in the Early Childhood Islamic Education Study Program (PIAUD). Peers assess by giving a score on each questionnaire statement. Also, the assessment is carried out by providing suggestions for improvement. These two validators are students of the Masters of Islamic Education in the Early Childhood Faculty of Tarbiyah and Teacher Training at UIN Sunan Kalijaga.

\section{Revision of The Validator}

The following are some of the revisions made after the validation process, both by media experts, material experts, Al-Washliyah management, and colleagues. The corrective notes submitted by the validator serve as a reference in revising the product. Researchers made the following revisions:

1. Font size changed from 12 to 14 according to the advice of media experts. The following changes in font size made by researchers.
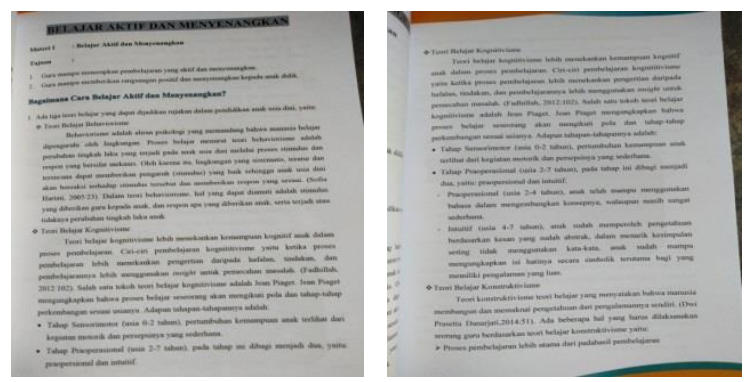

2. According to media experts' advice, this module needs to be added by other essential components such as Introduction (rational, description, relevance), Summary, Test assignment, Final test, Glossary, Answer key. Changes to essential components in the module can be seen as follows:
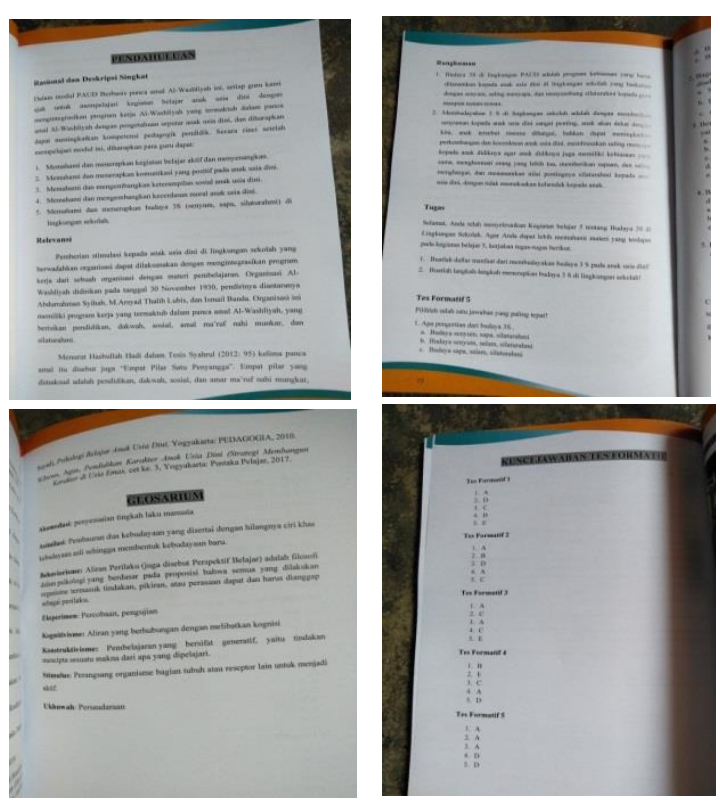
Mhd. Habibu Rahman, Maemonah/ Development of Module Early Childhood Education Based on Panca Amal Al-

Washliyah to Improve Teacher's Pedagogic Competence in Ra Al-Washliyah Kisaran Kabupaten Asahan Sumatera Utara

3. This module needs to be added with creative images to adjust the five Al-Washliyah charities. This is by the expert advice of the material. The following are the addition of creative images conducted by researchers.
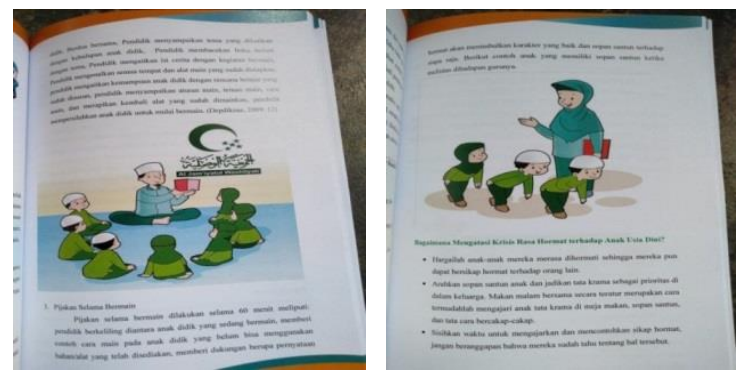

\section{E. Expert Validation Testing Results}

Researchers' initial product was given to media experts, material experts, Al-Washliyah administrators, and colleagues to validate. This study's data were provided by giving a questionnaire that included 18 assessment items in terms of appearance, presentation, and material aspects. Initial data in the form of ordinal data are converted to interval data with the Successive Interval Method (MSI). The following are the results of the validator's assessment, which has been converted into interval data.

\section{F. Product Testing}

The initial product has been validated by the validators and has been revised based on expert improvement recommendations. Then the researchers tested the product on educators at RA Al-Washliyah Kisaran Asahan Regency. According to the module's material, these four educators were given products from the PAUD-based AI-Washliyahbased PAUD Module and conducted activities with students. Previously, educators were given a pretest question to know the teacher's pedagogical competency knowledge before studying the AlWashliyah-based PAUD Module.

The data obtained from this product trial consists of teacher response data to the PAUDbased Al-Washliyah-based PAUD Module. Data from observations of teacher pedagogical competency activities in carrying out learning by utilizing the PA-Al-Washliyah-based PAUD Module.

1. Educator response to PAUD-based AlWashliyah-based PAUD modules

One of the product trial data that was taken into consideration was product revision, one of which was the educator's response to the Panca Amal Al-
Washliyah-based PAUD module. Researchers provide modules on the subject of research trials for this product to be studied as well as possible. Researchers also use this module for the implementation of Al-Washliyah's five charities in early childhood. After the research subjects learn and follow the researchers' activities in the module, then a questionnaire is given to measure the response of the research subjects (educators) to the PAUD-based module of AI-Washliyah-based PAUD.

The response for educators includes modules design aspects, grammar, module presentation, the usefulness of the material in improving teacher pedagogical competence, and breadth of material. Data on the results of educator responses in product trials to the PAUD-based module of Al-Washliyah-based Panca Amal and data that has been transmitted using the successive interval (MSI) method are presented in the following table:

Table 1. Educator Response Interval Data

\begin{tabular}{|c|c|c|c|c|}
\hline \multirow{2}{*}{$\begin{array}{l}\text { Item } \\
\text { Perny } \\
\text { ataan }\end{array}$} & \multicolumn{4}{|c|}{ Guru } \\
\hline & 1 & 2 & 3 & 4 \\
\hline 1 & 1 & 1 & 2,5957 & 2,8286 \\
\hline 2 & 1 & 2,6948 & 2,5957 & 2,8286 \\
\hline 3 & 1 & 1 & 1 & 2,8286 \\
\hline 4 & 2,6097 & 1 & 1 & 2,8286 \\
\hline 5 & 2,6097 & 1 & 2,5957 & 2,8286 \\
\hline 6 & 2,6097 & 1 & 2,5957 & 1 \\
\hline 7 & 2,6097 & 2,6948 & 1 & 1 \\
\hline 8 & 2,6097 & 1 & 1 & 2,8286 \\
\hline 9 & 1 & 1 & 1 & 2,8286 \\
\hline 10 & 2,6097 & 1 & 2,5957 & 2,8286 \\
\hline 11 & 1 & 2,6948 & 2,5957 & 1 \\
\hline 12 & 1 & 1 & 1 & 2,8286 \\
\hline 13 & 2,6097 & 2,6948 & 1 & 2,8286 \\
\hline 14 & 1 & 1 & 2,5957 & 2,8286 \\
\hline 15 & 1 & 1 & 2,5957 & 2,8286 \\
\hline 16 & 2,6097 & 1 & 2,5957 & 2,8286 \\
\hline 17 & 1 & 1 & 1 & 2,8286 \\
\hline 18 & 1 & 1 & 2,5957 & 2,8286 \\
\hline 19 & 1 & 2,6948 & 1 & 2,8286 \\
\hline 20 & 1 & 1 & 1 & \\
\hline
\end{tabular}

\section{Teacher Pedagogic Competency Improvement Achievement}

Achievement of increasing teacher pedagogical competence can be assessed from the pretest-posttest results to increase knowledge and 
Golden Age: Jurnal Pendidikan Anak Usia Dini, Volume 3 Nomor 2 (Desember 2019) ISSN 2549-8371 | E-ISSN 2580-5843

Mhd. Habibu Rahman, Maemonah/ Development of Module Early Childhood Education Based on Panca Amal AlWashliyah to Improve Teacher's Pedagogic Competence in Ra Al-Washliyah Kisaran Kabupaten Asahan Sumatera Utara

observations made by researchers to observe teacher pedagogical competence. The following are the results of the pretest-posttest.

Table 2. Achievements in Increasing Knowledge of Teacher Pedagogical Competencies

\begin{tabular}{|c|c|c|c|c|}
\hline \multirow[t]{2}{*}{ Crite } & \multicolumn{4}{|c|}{ Teacher Name } \\
\hline & Zuh & Shola & Fauziah & Siti A \\
\hline Score & 10 & 10 & 18 & 11 \\
\hline \multicolumn{5}{|l|}{ Pre } \\
\hline Score & 23 & 24 & 29 & 26 \\
\hline \multicolumn{5}{|l|}{ post } \\
\hline Selisih & 13 & 14 & 11 & 15 \\
\hline Gain & 0,65 & 0,70 & 0,91 & 0,78 \\
\hline stan & & & & \\
\hline Rate & 12,25 & 25,50 & 13,25 & 0,76 \\
\hline $\begin{array}{l}\text { Interpr } \\
\text { etation }\end{array}$ & Medium & High & High & High \\
\hline
\end{tabular}

\section{G. Data Analysis}

1. Data Analysis of the Module Feasibility Validation Results

Data obtained from the validation of media experts, material experts, Al-Washliyah administrators, and peers to the Al-Washliyah-based PAUD-based PAUD Module products were developed, analyzed, and used a reference for revision. The results of validation from media experts, material experts, Al-Washliyah management, peers who have reviewed in terms of appearance, presentation, and material by table 1 show that from 18 items of statements given to six validators, all of them received positive values.

\section{Product Trial Data Analysis}

Other assessments aside from media experts, material experts, Al-Washliyah administrators, and colleagues. Educators' responses to the PAUD-Based Al-Washliyah-based PAUD module were also used as data for module improvement. On taking product trial data to 4 educators. The process of taking the product trial data is carried out by the researcher communicating directly to the educator to explain the learning activities in the module and the play activities of the educator to the students. Furthermore, educators are welcome to respond by filling out the questionnaire provided.

The results of educator responses based on table 2 after the data was converted into interval data showed that of the 20 items of statements given to 4 educators received positive values. It can be concluded in product trials that this module gets a very positive response from educators. Educators involved in testing this product also gave much criticism in terms of writing errors. This criticism is an input for module improvement.

In addition to being seen from the pretest and post-test results, the achievement of increasing teacher pedagogical competence can also be seen from the observation of the teacher's activities during the implementation of the Al-Washliyah Five Charity Program in learning. By emphasizing pedagogical competence through five indicators, namely active and enjoyable learning, positive communication, social skills, moral intelligence, and 3S culture (smile, greetings, hospitality). These five indicators are contained in 10 aspects that were assessed. The following table is an observation of the teacher's pedagogical competence in product testing.

\section{Analysis of Teacher Pedagogical Competency Improvement Achievement}

The development of the Panca Amal AlWashliyah-based PAUD module was designed to increase teacher pedagogical competence. For this reason, the achievement of increasing teacher pedagogical competence can be seen from two aspects assessed, namely the knowledge aspect taken from the pretest-posttest value. Other data are observations of teacher pedagogical competency activities when teaching.

The results of the pretest-posttest are shown in table 4 . The average pretest score was 12.25, while the post-test was 25.50. Educators have increased 13.25 with a standard gain of 0.76 , which is in the "high" category. So, the use of modules has a strong influence on increasing the teacher's pedagogical skills knowledge.

To measure the teacher's pedagogical competence, the researcher analyzed the teacher's pedagogical competency activities in the five AlWashliyah charitable activities in learning assisted by two observers. The average score of observations obtained from observer I and observer II is 4.65 , which is in the percentage of $93 \%$, so it is said to be in the "Very High" category.

\section{Product Revision}

This product revision was carried out based on the advice of media experts, material experts, AlWashliyah administrators, peers, and findings in the 
field during product trials. The researcher made the first revision after validation with media experts and material experts. The second revision was made after getting suggestions for improvement from the Al-Washliyah management and colleagues. The revision description in the first and second stages has been submitted in the previous discussion.

At this stage, the product revision in question is a revision based on the product trial findings. Revisions made to product trials include the addition of pictures and verses of the Qur'an and the traditions as a hallmark of AI-Washliyah, the addition of religious material, and requests for more modules for early childhood for schools to rely on the AlWashliyah organization.

\section{Final Product Review}

The Panca Amal AI-Washliyah-based PAUD Module has been developed. Stages by stage of development have been carried out, including analyzing developed products, making prototypes of initial products, validating media experts, material experts, Al-Washliyah administrators, and peers. Next is the product revision. After revising, the product was tested. The next step is to make revisions based on field findings and try out on a large scale.

The development steps were taken by the researchers in this case only reached the product trial. Then the final product was obtained. Researchers have not conducted widespread use trials. This is because of time and cost constraints that prevent researchers from reaching that stage. The final product that has gone through a long stage of development in the form of the PAUD-based AlWashliyah-based PAUD Module, which is generally described as follows:

\section{Display Aspects}

The Panca Amal Al-Washliyah-based PAUD Module experienced changes in the size of the letters used, the appearance of the "Did you know" reinforcement box, the addition of illustrated images, and the use of tables in some material.

\section{Presentation Aspects}

In the final product, the systematic presentation is as follows:

a. Cover;

b. Module Editor;

c. Preface;

d. Table of Contents;

e. Introduction. Includes: Rational and Brief Descriptions, Relevance, Programs in Modules, and Instructions for Using Modules; f. They were learning Activities 1 to 5 . For the presentation of the material presented in language that is easily understood in the form of points, it reduces boredom and boredom for every reader. Some material is presented with visualization to make it easier for readers to understand its contents;

g. Each learning activity consists of learning achievements, sub learning outcomes, material description, activities let us play, let us tell stories, let us a record, did you know? Summaries, assignments, and formative tests;

h. Final Project;

i. Bibliography;

j. Glossary;

k. Key Formative Test Answers; and

I. Author Biography.

\section{Material Aspects}

From the initial product to the final product, the material in this module experiences the addition of material about Al-Qur'an verses and Al-Washliyah material.

\section{CONCLUSION}

Based on data analysis and discussion, conclusions can be drawn as follows: The development of the Al-Washliyah-based PAUDbased PAUD Module has been carried out until the large-scale trial stage has not yet reached the stage of widespread use due to time and cost limitations. The Panca Amal AI-Washliyah-based PAUD module was developed based on validation data analysis. Both media experts, material experts, Al-Washliyah administrators, and colleagues received positive responses. The results of educators' responses to the Panca Amal Al-Washliyah-based PAUD Module in small scale trials and large scale trials both show positive gradients, so it can be concluded that this module is suitable for use.

The pretest and post-test results based on the analysis of research data showed an increase in knowledge of high teacher pedagogical competence with an average pretest value of 12.25 while the average post-test was 25.50 so that it had increased by 13.25 with a standard gain of 0.76 on product trials. The standard gain value is classified in the "high" category. Observation of teacher pedagogical competency activities using the PAUD-Based Module of AI-Washliyah-based PAUD also reached an average score of 4.65 in the percentage of $93 \%$ so that it was included in the "very high" category. Thus the use of the Al-Washliyah-based PAUD- 
based PAUD Module is considered effective in increasing teacher pedagogical competence.

\section{REFERENCES}

AD/ART Al Washliyah. (2010). Jakarta: PB AlWashliyah.

Akhyak, Idrus, M., Bakar, Y. A. (2013). Implementation of Teachers Pedagogy Competence to Optimizing Learners Development in Public Primary School in Indonesia Lecturer of State Islamic University (STAIN), Tulungagung, East Java, Indonesia. STAIN. 1(9), 1-10.

Borg, W. R., \& M.D. Gall. (1983). Educational Research: An Intrucdation. New York: Longman.

Depdiknas. (2003). Pedoman Penulisan Modul. jakarta: Direktorat LPP, Ditjend Dikdsamen, Depdiknas.

Depdiknas. (2008). Penulisan Modul. jakarta: PMPTK.

E. Mulyasa. (2009). Kurikulum Yang Disempurnakan Pengembangan Standar Kompetensi dan Kompetensi Dasar. Bandung: Rosdakarya.

Kamus Besar Bahasa Indonesia Offline Versi 1.1 (Digital). (2010).

Marselus R. Payong. (2011). Sertifikasi Profesi Guru. Jakarta: Indeks.

PB Al-Washliyah. (2012). Pedoman Penyelenggaran Pendidikan Anak Usia Dini, Pendidikan Dasar, dan Pendidikan Menengah. Jakarta.

Pendidikan, M., Kebudayaan, D. A. N., \& Indonesia, R. (2014).

Purwanto, A. R., \& Suharto Lasmono. (2007). Pengembangan Modul. Jakarta: Depdiknas Pustekkom.

Rayandra Asyhar. (2011). Kreatif Mengembangkan Media Pembelajaran. Jakarta: Referensi Jakarta.

Riza, F. (2013). Transformasi Al-Washliyah: Dari Gerakan Kultural ke Politik Elektoral. 5(2), 48-58.

Sugiyono. (2016). Metode Penelitian dan Pengembangan, Research and Development, Cet. 2. Bandung: Alfabeta.

Sukmadinata, N. S., \& Syaodih, E. (2012). Kurikulum dan Pembelajaran Kompetensi. Bandung: Refika Aditama.

Suyanto, \& Asep Jihad. (2013). Menjadi Guru Profesional Strategi Meningkatkan Kualifikasi dan Kualitas Guru di Era Global. Jakarta: Esensi Erlangga Group.

Syahrul. (2012). Tesis. Strategi Pengembangan Ekonomi Umat Melalui Penguatan Peran Ormas Islam di Kabupaten Asahan. Medan: Program Pasca Sarjana IAIN Sumatera Utara. 